\title{
Effects of Seed Storage Conditions on Biochemical Changes of Freshly Harvested High Moisture Undried Rice Seeds cv. CO 51
}

\author{
V. Marthandan ${ }^{1 *}$ and R. Jerlin ${ }^{2}$ \\ ${ }^{1}$ Department of Seed Science and Technology, Tamil Nadu Agricultural University, \\ Coimbatore - 641 003, Tamil Nadu, India \\ ${ }^{2}$ Department of Seed Science and Technology, Agricultural Research Station, \\ Bhavanisagar, Tamil Nadu, India \\ *Corresponding author
}

\begin{tabular}{|c|c|}
\hline \multicolumn{2}{|r|}{ A B S T R A C T } \\
\hline & \multirow{8}{*}{$\begin{array}{l}\text { Freshly harvested high moisture undried rice seeds will induce the deterioration rapidly, it } \\
\text { affect the storability of the seed material. The present study was carried out to access the } \\
\text { biochemical changes of high moisture and dried seeds taking place under cold and ambient } \\
\text { storage condition. The freshly harvested high moisture rice seeds was harvested and stored } \\
\text { under cold and ambient storage condition for } 15 \text { days in Department of Seed Science and } \\
\text { Technology, Tamil Nadu Agricultural University, Coimbatore. In order to know the } \\
\text { effectiveness of the storage condition the seeds drawn at } 5,10 \text { and } 15 \text { days after storage } \\
\text { and it was dried to optimum moisture content, followed by the enzymatic changes was } \\
\text { carried out viz., dehydrogenase, } \alpha \text { - amylase, catalase and peroxidase. The seeds under cold } \\
\text { storage performed better than ambient storage condition. The enzymes which will helps } \\
\text { the storability of seed was maximum in undried and dried seeds stored under cold storage } \\
\text { condition viz., Dehydrogenase ( } 0.174 \text { and } 0.773 \text { OD value), } \alpha \text { - amylase }(1.38 \text { and } 1.43 \mathrm{mg} \\
\text { maltose min.-1), due to lower respiratory activity in seeds, which was higher than the } \\
\text { ambient storage condition. The rising of enzyme activity in undried and dried seeds stored } \\
\text { under ambient condition such as Catalase }\left(4.228 \text { and } 4.210 \mu \mathrm{gg} \mathrm{H}_{2} \mathrm{O}_{2} \mathrm{mg}^{-1} \text { min }{ }^{-1}\right) \text {, } \\
\text { Peroxidase activity }\left(2.27 \text { and } 2.12 \mathrm{~m} \text { moltetraguaicol g } \mathrm{g}^{-1}\right) \text {, will shown signaling of seed } \\
\text { deterioration. }\end{array}$} \\
\hline & \\
\hline & \\
\hline & \\
\hline & \\
\hline Article Info & \\
\hline $\begin{array}{l}\text { Accepted: } \\
\text { 19 October } 2017 \\
\text { Available Online: } \\
10 \text { December } 2017\end{array}$ & \\
\hline & \\
\hline
\end{tabular}

\section{Introduction}

Changes in free radical scavenging enzymes, increased free radical production, degradation of protein and DNA and increase in free amino acid were attributed to reduce the germination and seedling vigour during ageing (McDonald, 2004). Decrease in enzymatic activity in stored seeds with increase in storage time resulted reduction in germination and vigour (Khan et al., 2013).The biochemical parameters viz., electrical conductivity, dehydrogenase, $\alpha$ - amylase, catalase, peroxidase and superoxide dismutase activity were measured quantitatively. The activity of all the enzymes had decreased at subsequent storage interval under natural ageing. Chauhan et al., (2011) studied the level of various enzymes and found that reason might be cause of seed deterioration under natural ageing is decrease in enzyme activity in seeds lowers its respiratory potential, which in turn lowers both the energy (ATP) and food supply to the 
germinating seed. Several changes in the enzyme macromolecular structure may contribute to their lower effectiveness. They may undergo compositional changes by losing or gaining certain functional groups, by oxidation of sulfhydral groups or by conversion of amino acids within the protein structure

\section{Materials and Methods}

\section{Dehydrogenase activity (OD Value)}

For estimating the dehydrogenase activity and utilizing it as a measure of seed vigour, $0.5 \%$ 2, 3, 5-triphenyl tetrazolium chloride solution dissolved in Sorenson's buffer solution as solvent was used. Three replication of ten seeds from each variety were taken and preconditioned by soaking in water for $7 \mathrm{~h}$. Seeds were soaked in tetrazolium solution and kept in dark for $2 \mathrm{~h}$ at $40^{\circ} \mathrm{C}$ for staining. After staining, the excess solution was drained and the seeds were washed thoroughly with distilled water and transferred to a test tube containing $5 \mathrm{ml}$ of 2-methoxy ethanol (Methyl Cellosolve). The test tube was closed air tight and allowed to remain in the incubator in darkness overnight for extracting the red coloured formazon. The coloured solution was decanted and the colour intensity was measured in an ELICO UV-VIS Spectrophotometer (Model SL-159) using blue filter $(470 \mathrm{~nm})$ with Methyl Cellosolve as the blank. The OD value obtained was reported as dehydrogenase activity (Kittock and Law, 1968).

\section{a-Amylase activity (mg maltose/min)}

Three replicates of $500 \mathrm{mg}$ of each pregerminated seed samples were homogenised in $1.8 \mathrm{ml}$ of cold $0.02 \mathrm{M}$ sodium phosphate buffer ( $\mathrm{pH} \mathrm{6.0)}$ and centrifuged at $20000 \mathrm{rpm}$ for $20 \mathrm{~min}$. to extract enzymes. To the $0.1 \mathrm{ml}$ of enzyme extract, one $\mathrm{ml}$ of 0.067 per cent starch solution was added. The reaction was stopped after $10 \mathrm{~min}$. of incubation at $25^{\circ} \mathrm{C}$ by the addition of one $\mathrm{ml}$ of iodine $\mathrm{HCl}$ solution (60 mg KI and $6 \mathrm{mg} \mathrm{I} 2$ in $100 \mathrm{ml}$ of $0.05 \mathrm{~N}$ $\mathrm{HCl})$. Change in colour was measured at 620 $\mathrm{nm}$ Spectrophotometer (Model SL-159). The activity was calculated and expressed as $\mathrm{mg}$ maltose/min (Paul et al., 1970).

$\alpha$-amylase activity $=\frac{\text { OD Value }}{\text { Volume of sample pipetted out }} \times \frac{1000}{500}$

\section{Protease activity (OD value)}

One $\mathrm{ml}$ of embryo extract was added to 0.5 $\mathrm{ml}$ of 1 per cent casein solution containing $0.1 \mathrm{M}$ Tris-HC1 buffer $(\mathrm{pH}$ 8.5). After incubation at $37^{\circ} \mathrm{C}$ for $30 \mathrm{~min}$. the reaction was stopped by adding $1.25 \mathrm{ml}$ of $5 \%$ of Tricarboxylic acetic acid (TCA). After $1 \mathrm{~h}$ at room temperature the precipitate was filtered and the absorbance of the filtrate was read at $280 \mathrm{~nm}$ in an Optima UV-VIS spectrophotometer (Model SP-3000) against a blank prepared by adding casein solution to the incubation mixture after TCA. An increase in 0.01 absorbance unit at $280 \mathrm{~nm}$ under the conditions of assay was considered as one protease activity unit. The protease activity was measured as OD value (Naithani, 1987).

\section{Catalase ( $\mu \mathrm{mol} \mathrm{min} .^{-1} \mathrm{~g}^{-1}$ seed)}

Catalase assay is based on the absorbance of $\mathrm{H}_{2} \mathrm{O}_{2}$ at $240 \mathrm{~nm}$ in UV-range. A decrease in the absorbance is recorded over a time period as described by Aebi (1984).

Adding $\mathrm{H}_{2} \mathrm{O}_{2}$ started reaction and decrease in absorbance at $240 \mathrm{~nm}$ was recorded for one minute in an ELICO UV-VIS spectrophotometer (Model SL-159). Enzyme activity was computed by calculating the amount of $\mathrm{H}_{2} \mathrm{O}_{2}$ decomposed. The initial and final contents of hydrogen peroxide are 
calculated by comparing with a standard curve drawn with known concentrations of hydrogen peroxide. Enzyme activity is calculated as concentration of hydrogen peroxide reduced (initial reading - final reading $=$ quantity of hydrogen peroxide reduced in $\mu \mathrm{mol})$ per min. per gram fresh weight of seed ( $\mu$ mol min. ${ }^{-1} \mathrm{~g}^{-1}$ seed).

\section{Peroxidase (m moltetraguaicol $\mathbf{g}^{-1}$ )}

Peroxidase activity was assayed as increase in optical density due to the oxidation of guaiacol to tetraguaiacol (Castillo et al., 1984). Absorbance due to the formation of tetra-guaiacol was recorded at $470 \mathrm{~nm}$ in Spectrophotometer (Model SL-159) and enzyme activity was calculated as per extinction coefficient of its oxidation product, tetraguaiacol $\left(\in=26.6 \mathrm{mM}^{-1} \mathrm{~cm}^{-1}\right)$. Enzyme activity is expressed as $\mathrm{m}$ moltetraguaiacol formed min. $^{-1} \mathrm{~g}^{-1}$ seed.

\section{Results and Discussion}

There was significant difference observed in biochemical properties of freshly harvested high moisture rice seeds stored under cold and ambient storage condition. The rice seeds were harvested and stored with high moisture content without drying for 15 days and the seeds taken back after 5,10 and 15 days after storage evident that, storability of rice seeds with high moisture was not spoiling when its adopt with cold storage. Narayana Murthy et $a l$. , (2003) reported that causes of seed ageing such as lipid peroxidation mediated by free radicals, inactivation of enzymes or decrease in proteins, disintegration of cell membranes and genetic damage. The enzymes which will help the storability of seed were maximum in undried and dried seeds stored under cold storage condition viz., Dehydrogenase $(0.174$ and 0.773 OD value) and it was (0.1677 and 0.163 OD value) under ambient condition. 5, 10 and 15 DAS the dehydrogenase activity was increased in undried and dried seeds. Under the cold storage condition the dehydrogenase activity (0.174) was $4.2 \%$ higher than the ambient storage (0.167) condition (Table 1). This result is in agreement with the findings of Raja (2003), Ramanadane (2003) in rice and Basavarajappa et al., (1991) in maize.

The dehydrogenase enzyme activity is a good stable metabolic marker to estimate the degree of vigour in seeds (Saxena et al., 1987) and have positive association with vigour and viability of seeds (Rudrapal and Basu, 1979; Halder and Gupta, 1982). Irrespective of undried and dried seeds $\alpha$ amylase (activity was 1.38 and $1.43 \mathrm{mg}$ maltose min. ${ }^{-1}$ ) was $2 \%$ higher in cold storage condition than the ambient storage condition (Table 2).

Seeds stored and dried after 5, 10 and 15 days after drying has retain higher level of $\alpha$ amylase activity in cold storage condition which was maintain $1.4 \%$ higher activity with 15 days of storage period. $\alpha$-amylase activity actually represents the predominant contribution of the carbohydrate metabolism in endosperm of rice seeds and represents the variable spectrum of germination potential (seed vigour) of sindh rice cultivars (Galani et $a l ., 2011)$ due to lower respiratory activity in seeds, which was higher than the ambient storage condition.

The rate of respiration was minimum in the cold storage conditions which will helps to reduce the enzymatic reaction which will induce the deterioration process. Ramegowda (1992) reported a decrease in the activity of enzymes viz., $\alpha$-amylase, catalase and peroxidase, coupled with progressive ageing of rice seeds. He further authenticated that $\alpha$ amylase and peroxidase enzymes were more directly involved in the maintenance of better germination of differentially aged seeds. 
Table.1 Effect of cold and ambient storage conditions on dehydrogenase (OD Value $10^{-1}$ seeds) activity of freshly harvested high moisture rice seeds cv. CO 51

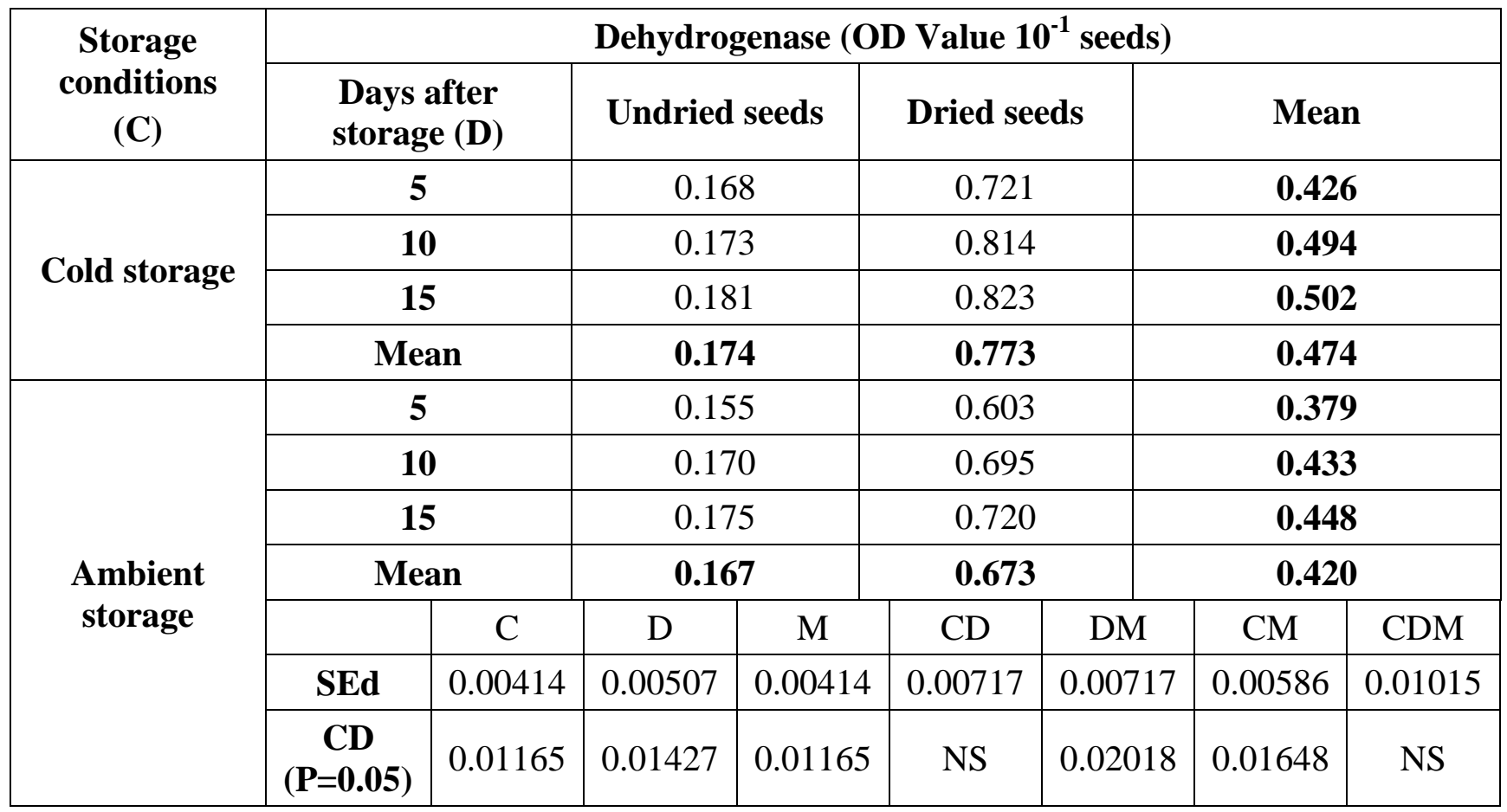

Table. 2 Effect of cold and ambient storage conditions on $\alpha$ - amylase (mg maltose min. ${ }^{-1}$ ) activity of freshly harvested high moisture rice seeds cv. CO 51

\begin{tabular}{|c|c|c|c|c|c|c|c|c|c|}
\hline \multirow{2}{*}{$\begin{array}{c}\text { Storage } \\
\text { conditions } \\
\text { (C) }\end{array}$} & \multicolumn{9}{|c|}{$\alpha$ - amylase activity (mg maltose min. $^{-1}$ ) } \\
\hline & \multicolumn{2}{|c|}{$\begin{array}{c}\text { Days after } \\
\text { storage }(D)\end{array}$} & \multicolumn{2}{|c|}{ Undried seeds } & \multicolumn{2}{|c|}{ Dried seeds } & \multicolumn{3}{|c|}{ Mean } \\
\hline \multirow{4}{*}{ Cold storage } & \multicolumn{2}{|l|}{5} & \multicolumn{2}{|l|}{1.37} & \multicolumn{2}{|r|}{1.46} & \multicolumn{3}{|c|}{1.391} \\
\hline & \multicolumn{2}{|c|}{10} & \multicolumn{2}{|l|}{1.37} & \multicolumn{2}{|r|}{1.44} & \multicolumn{3}{|c|}{1.398} \\
\hline & \multicolumn{2}{|c|}{15} & \multicolumn{2}{|l|}{1.39} & \multicolumn{2}{|r|}{1.40} & \multicolumn{3}{|c|}{1.41} \\
\hline & \multicolumn{2}{|c|}{ Mean } & \multicolumn{2}{|l|}{1.38} & \multicolumn{2}{|r|}{1.43} & \multicolumn{3}{|c|}{1.399} \\
\hline \multirow{7}{*}{$\begin{array}{l}\text { Ambient } \\
\text { storage }\end{array}$} & \multicolumn{2}{|c|}{5} & \multicolumn{2}{|l|}{1.35} & \multicolumn{2}{|r|}{1.40} & \multicolumn{3}{|c|}{1.380} \\
\hline & \multicolumn{2}{|c|}{10} & \multicolumn{2}{|l|}{1.36} & \multicolumn{2}{|r|}{1.41} & \multicolumn{3}{|c|}{1.393} \\
\hline & \multicolumn{2}{|c|}{15} & \multicolumn{2}{|l|}{1.37} & \multicolumn{2}{|r|}{1.42} & \multicolumn{3}{|c|}{1.397} \\
\hline & \multicolumn{2}{|c|}{ Mean } & \multicolumn{2}{|l|}{1.36} & & 1.41 & & 1.390 & \\
\hline & & $\mathrm{C}$ & $\mathrm{D}$ & $\mathrm{N}$ & & $\mathrm{CD}$ & $\mathrm{DM}$ & $\mathrm{CM}$ & $\mathrm{CDM}$ \\
\hline & SEd & 0.00973 & 0.01192 & 0.00 & & 0.01686 & 0.01686 & 0.01377 & 0.02384 \\
\hline & $\begin{array}{c}\text { CD } \\
(P=0.05)\end{array}$ & 0.02738 & NS & 0.02 & & NS & NS & NS & NS \\
\hline
\end{tabular}


Table.3 Effect of cold and ambient storage conditions on catalase $\left(\mu \mathrm{mol} \mathrm{H}_{2} \mathrm{O}_{2}\right.$ reduced min. ${ }^{-1} \mathrm{~g}^{-1}$ seed) activity of freshly harvested high moisture rice seeds cv. CO 51

\begin{tabular}{|c|c|c|c|c|c|c|c|c|}
\hline \multirow{2}{*}{$\begin{array}{c}\text { Storage } \\
\text { conditions } \\
\text { (C) } \\
\end{array}$} & \multicolumn{8}{|c|}{ Catalase $\left(\mu \mathrm{mol} \mathrm{H}_{2} \mathrm{O}_{2}\right.$ reduced $\mathrm{min}^{-1} \mathrm{~g}^{-1}$ seed $)$} \\
\hline & $\begin{array}{c}\text { Days after } \\
\text { storage (D) }\end{array}$ & \multicolumn{3}{|c|}{ Undried seeds } & \multicolumn{2}{|c|}{ Dried seeds } & \multicolumn{2}{|c|}{ Mean } \\
\hline \multirow{4}{*}{$\begin{array}{c}\text { Cold } \\
\text { storage }\end{array}$} & 5 & \multicolumn{3}{|c|}{4.198} & \multicolumn{2}{|l|}{4.186} & \multicolumn{2}{|c|}{4.192} \\
\hline & 10 & \multicolumn{3}{|c|}{4.202} & \multicolumn{2}{|l|}{4.188} & \multicolumn{2}{|c|}{4.195} \\
\hline & 15 & \multicolumn{3}{|c|}{4.207} & \multicolumn{2}{|l|}{4.192} & \multicolumn{2}{|c|}{4.200} \\
\hline & Mean & \multicolumn{3}{|c|}{4.202} & \multicolumn{2}{|l|}{4.189} & \multicolumn{2}{|c|}{4.196} \\
\hline \multirow{7}{*}{$\begin{array}{c}\text { Ambient } \\
\text { storage }\end{array}$} & 5 & \multicolumn{3}{|c|}{4.213} & \multicolumn{2}{|l|}{4.201} & \multicolumn{2}{|c|}{4.211} \\
\hline & $\mathbf{1 0}$ & \multicolumn{3}{|c|}{4.223} & \multicolumn{2}{|l|}{4.209} & \multicolumn{2}{|c|}{4.219} \\
\hline & 15 & \multicolumn{3}{|c|}{4.247} & \multicolumn{2}{|l|}{4.221} & \multicolumn{2}{|c|}{4.231} \\
\hline & Mean & \multicolumn{3}{|c|}{4.228} & 4.210 & & \multicolumn{2}{|c|}{4.219} \\
\hline & & $\mathrm{C}$ & $\mathrm{D}$ & $\mathrm{M}$ & $\mathrm{CD}$ & DM & $\mathrm{CM}$ & CDM \\
\hline & SEd & 0.01762 & 0.02158 & 0.01762 & 0.03052 & 0.0305 & 0.02492 & 0.04316 \\
\hline & $\begin{array}{c}\text { CD } \\
(\mathbf{P}=\mathbf{0 . 0 5})\end{array}$ & 0.04956 & 0.06070 & 0.04956 & NS & NS & NS & NS \\
\hline
\end{tabular}

Table.4 Effect of cold and ambient storage conditions on peroxidase activity (m moltetraguaicol $\mathrm{g}^{-1}$ ) of freshly harvested high moisture rice seeds cv. CO 51

\begin{tabular}{|c|c|c|c|c|c|c|c|c|}
\hline \multirow{2}{*}{$\begin{array}{c}\text { Storage } \\
\text { conditions } \\
\text { (C) }\end{array}$} & \multicolumn{8}{|c|}{ Peroxidase activity (m moltetraguaicol $\mathrm{g}^{-1}$ ) } \\
\hline & $\begin{array}{l}\text { Days after } \\
\text { storage(D) }\end{array}$ & \multicolumn{3}{|c|}{ Undried seeds } & Dried seeds & \multicolumn{3}{|c|}{ Mean } \\
\hline \multirow{4}{*}{$\begin{array}{c}\text { Cold } \\
\text { storage }\end{array}$} & 5 & \multicolumn{2}{|c|}{1.98} & & 1.78 & \multicolumn{3}{|c|}{1.88} \\
\hline & 10 & \multicolumn{2}{|c|}{2.02} & & 1.86 & \multicolumn{3}{|c|}{1.94} \\
\hline & 15 & \multicolumn{2}{|c|}{2.16} & & 1.94 & \multicolumn{3}{|c|}{2.05} \\
\hline & Mean & \multicolumn{2}{|c|}{2.05} & & 1.86 & \multicolumn{3}{|c|}{1.96} \\
\hline \multirow{7}{*}{$\begin{array}{c}\text { Ambient } \\
\text { storage }\end{array}$} & 5 & \multicolumn{2}{|c|}{2.19} & & 2.02 & \multicolumn{3}{|c|}{2.10} \\
\hline & 10 & \multicolumn{2}{|c|}{2.23} & & 2.11 & \multicolumn{3}{|c|}{2.17} \\
\hline & 15 & \multicolumn{2}{|c|}{2.39} & & 2.23 & \multicolumn{3}{|c|}{2.31} \\
\hline & Mean & \multicolumn{2}{|r|}{2.27} & & 2.12 & \multicolumn{3}{|c|}{2.20} \\
\hline & & $\mathrm{C}$ & $\mathrm{D}$ & M & $\mathrm{CD}$ & $\mathrm{DM}$ & $\mathrm{CM}$ & CDM \\
\hline & SEd & 0.01687 & 0.02066 & 0.01687 & 0.02922 & 0.02922 & 0.02386 & 0.04132 \\
\hline & $\begin{array}{c}\text { CD } \\
(\mathbf{P}=0.05)\end{array}$ & 0.04744 & 0.05811 & 0.04744 & NS & NS & NS & NS \\
\hline
\end{tabular}

The seed coat and the internal seed properties in the freshly harvested high moisture undried seeds was not closely integrated, due to this reason the releasing of seed leachates will occur. Increasing heat induction and biochemical and enzymatic activities also found higher in ambient storage condition.
The rising of catalase activity in undried and dried seeds was reported in the seeds stored under ambient condition (4.228 and $4.210 \mu \mathrm{g}$ $\mathrm{H}_{2} \mathrm{O}_{2} \mathrm{mg}^{-1} \mathrm{~min}^{-1}$ ) and the minimum catalase activity was reported in the seeds stored under cold condition (4.202 and $4.189 \mu \mathrm{g} \mathrm{H}_{2} \mathrm{O}_{2} \mathrm{mg}^{-1}$ $\left.\min ^{-1}\right)$. After 5 days of storage the catalase 
activity was noticed minimum in cold condition and the maximum catalase activity was observed in ambient storage condition (Table 3). Catalase activity decreased in Melanoxylon brauna seeds under storage in maize and beans. Muniz et al., (2007) found different banding patterns for catalase, which was indicative that the enzyme is associated with the decomposition of hydrogen peroxide in cells. Reduction of catalase activity was also observed in onions during accelerated aging (Demirkaya et al., 2010). In ambient storage condition the complete loss of activity of enzymes may be due to the rapid oxidative stress caused due to high temperature and relative humidity.

The present study revealed that higher peroxidase activity $(2.27$ and $2.12 \mathrm{~m}$ moltetraguaicol $\mathrm{g}^{-1}$ ) was reported in seeds stored under ambient storage condition. The minimum peroxidase activity was observed in the undried and dried seeds stored under cold storage condition (1.98 and $1.78 \mathrm{~m}$ moltetraguaicol $\mathrm{g}^{-1}$ ) (Table 4). Peroxidase plays a critical role in seed metabolism by using hydrogen peroxide as an acceptor, which may increase defense mechanisms and prevent loss of quality (Ushimaru et al., 2001). In stored cotton seeds, peroxidase activity decreased after storage. The decline in peroxidase activity was also observed in Copaifera langsdorffi. In non-viable seeds, there is reduced activity of enzymes such as dehydrogenase, $\alpha$ - amylase and catalase, which can contribute significantly to the reduction of respiratory activity (Desai et al., 1997). Ageing in wheat was in association with accumulation of hydrogen peroxide (Lehner et al., 2008). Peroxidase activity was also reduced during storage of rice seeds (Zhou et al., 2002). Failure of aged seeds to germinate might be due to peroxidation, mitochondrial disfunction and less ATP production changes in membrane lipids therefore could account for the increase in solute leakage. Deterioration of cells in the rice embryonic axes depends on the balance between free radical accumulation and the activity of oxygen scavenging enzymes which constituted the active oxygen scavenging system during early imbibitions. They also recorded the loss of enzyme activity during prolonged storage of seeds under hot and humid conditions.

The present study was concluded that storing the high moisture undried rice seeds under cold storage is found best for slowdown the enzymatic activity of high moisture undried rice seeds when compared to the ambient storage condition.

\section{References}

Aebi, H. 1984. Catalase in vitro. Method Enzym. 105: 121-126.

Basavarajappa, B. S., Shetty, H. S., and Prakash, H. S. 1991. Membrane deterioration and other biochemical changes, associated with accelerated ageing of maize seeds. Seed Sci. and Technol. 19: 279-286.

Castillo, F. J., Panel, C., and Greppin, H. 1984. Peroxidase release induced by ozone in Sedum album leaves. Improvement of $\mathrm{Ca}^{2+}$. Plant Physiol. 74: 846.

Chauhan, D. S., Deswal, D. P., Dahiya, O. S., and Punia, R. C. 2011. Change in storage enzymes activities in natural and accelerated aged seed of wheat (Triticum aestivum). Seed Res. 48(1): 23-29.

Demirkaya, M., Dietz, K. J. H., and Sivritepe, O. 2010. Changes in antioxidant enzymes during ageing of onion seeds. Notulae Botanicae Horti Agrobotanic. 38: 49-52.

Desai, B. B., Kotecha, P. M., and Shalunke, D. K. 1997. Seed hand book - Biology, Production, Processing and Storage. Marcel Dekker. Inc. New York. 473-496.

Galani, S., Aman, A., and Qader, S. A. U. 2011. Germination potential index of Sindh rice cultivars on biochemical basis, using amylase as an indicator. African Journal of Biotechnology. 10(80): 18334-18338. 
Halder, S., and Gupta, K. 1982. On the mechanism of sunflower seed deterioration under low and high relative humidity. Seed Sci. and Technol. 10:267270.

Khan, M. M., Abbas, M., Awan, F. S., Shahid, M., Ali, M., and Ahmad, S. 2013. Physiobiochemical and genetic changes in stored pea (Pisum sativum) seeds. Int. J. Agric. Biol. 15(5): 951-956.

Kittock, D. L., and Law, A. G. 1968. Relationship of seedling vigour to respiration and tetrazolium reduction in germinating wheat seeds. Agron. J. 60: 268-288.

Lehner, A., Mamadou, N., Côme, D., Bailly, C., and Corbineau, F. 2008. Changes in soluble carbohydartes, lipid peroxidation and antioxidant enzyme activities in the embryo during ageing in wheat grains. Journal Cereal Science. 47:555-565.

McDonald, M. B. 2004. Orthodox seed deterioration and its repair. In: BenechArnold, R. L., and Sanchez, R.A. (Ed.), Handbook of Seed Physiology: Applications to Agriculture. Food Products Press, New York. pp. 273-304.

Muniz, F. R., Cardoso, M. G., Von Pinho, E. V. R., and Vilela, M. 2007. Qualidadefisiológica de sementes de milho, feijão, soja e alfacenapresença de extrato de tiririca. RevistaBrasileira de Sementes. 29: 195-204.

Naithani, S. C. 1987. The rate of IAA oxidase, peroxidase and poly phenol oxidase in the fibre initiation on the cotton ovule. Beitr. BiologiePflanzen. 62: 79-90.

Narayana Murthy, U. M., Prakash, P. Kumar and Wendell, Q. Sun. 2003. Mechanisms of seed ageing under different storage conditions for Vigna radiata (L.) Wilczek: lipid peroxidation, sugar hydrolysis, Maillard reactions and their relationship to glass state transition. J. Experimental Botany. 54(384): 1057-1067.

Paul, A. K., Erji, S. M., and Sircar, S. M. 1970. Metabolic changes in rice seeds during storage. Ind. J. Agric. Sci. 40(12):1031 1036.

Raja, K. 2003. Investigations on nursery and main field management techniques for quality seed production of rice hybrid CORH 2. Ph.D. Thesis. Tamil Nadu Agricultural University, Coimbatore.

Ramanadane. T. 2003. Studies on ecological influence and post-harvest seed management techniques on seed quality in hybrid rice (Oryza sativa L.). Ph.D. Thesis, Tamil Nadu Agricultural University, Coimbatore.

Ramegowda. 1992. Studies on seed senescence and seed vigour in some genotypes of rice. Ph.D. Thesis. Tamil Nadu Agriculture University, Coimbatore.

Rudrapal, A. B., and Basu, R. N. 1979. Physiology of hydration - dehydration treatment in the maintenance of seed viability in wheat (Triticum aestivum L.). Ind. J. Exp. Biol. 17: 768-771.

Saxena, O. P., Singh, G., Pakeeraiah, T., and Pandey, N. 1987. Seed deterioration studies in some vegetable seeds. Acta Hort. 215: 39-44.

Ushimaru, T., Kanematsu, S., Katayama, M., and Tsuji, H. 2001. Antioxicidative enzymes in seedling of Nelumbonucifera germinated under water. Physiologia Plantarum. 112:39-46.

Zhou, Z., Robards, K., Helliwell, S., and Blanchard, C. 2002. Ageing of stored rice changes in chemical and physical attributes. Journal of Cereal Science. 33: 65-78.

\section{How to cite this article:}

Marthandan, V. and Jerlin, R. 2017. Effects of Seed Storage Conditions on Biochemical Changes of Freshly Harvested High Moisture Undried Rice Seeds cv. CO 51. Int.J.Curr.Microbiol.App.Sci. 6(12): 2807-2813. doi: https://doi.org/10.20546/ijcmas.2017.612.326 